\title{
SOEP
}

SOEPpapers

on Multidisciplinary Panel Data Research

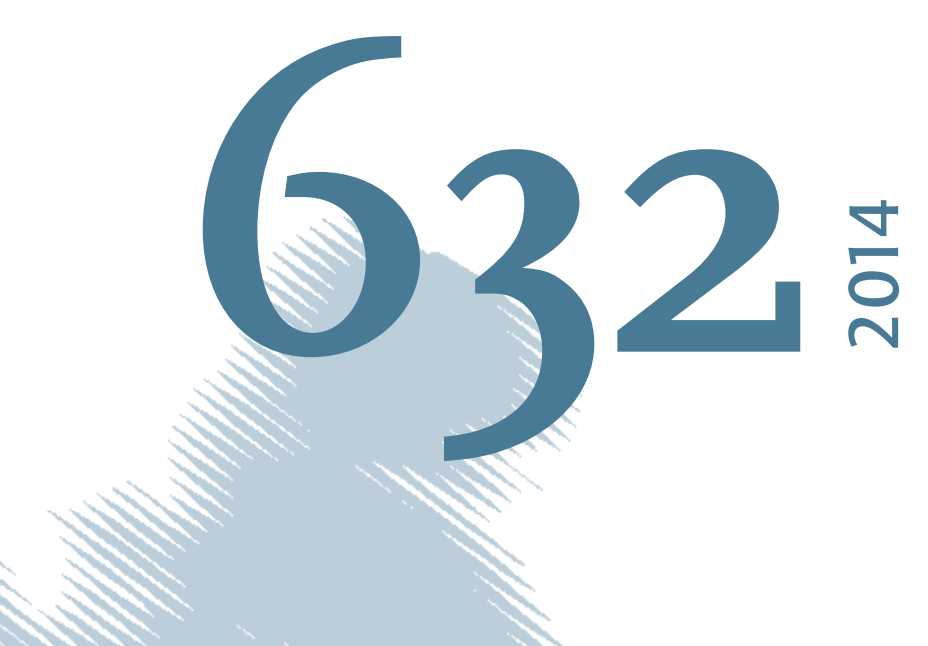

ए

\section{Measuring Fuel Poverty: General Considerations and Application to German Household Data}




\section{SOEPpapers on Multidisciplinary Panel Data Research}

at DIW Berlin

This series presents research findings based either directly on data from the German SocioEconomic Panel Study (SOEP) or using SOEP data as part of an internationally comparable data set (e.g. CNEF, ECHP, LIS, LWS, CHER/PACO). SOEP is a truly multidisciplinary household panel study covering a wide range of social and behavioral sciences: economics, sociology, psychology, survey methodology, econometrics and applied statistics, educational science, political science, public health, behavioral genetics, demography, geography, and sport science.

The decision to publish a submission in SOEPpapers is made by a board of editors chosen by the DIW Berlin to represent the wide range of disciplines covered by SOEP. There is no external referee process and papers are either accepted or rejected without revision. Papers appear in this series as works in progress and may also appear elsewhere. They often represent preliminary studies and are circulated to encourage discussion. Citation of such a paper should account for its provisional character. A revised version may be requested from the author directly.

Any opinions expressed in this series are those of the author(s) and not those of DIW Berlin. Research disseminated by DIW Berlin may include views on public policy issues, but the institute itself takes no institutional policy positions.

The SOEPpapers are available at

http://www.diw.de/soeppapers

\section{Editors:}

Jürgen Schupp (Sociology)

Gert G. Wagner (Social Sciences, Vice Dean DIW Graduate Center)

Conchita D'Ambrosio (Public Economics)

Denis Gerstorf (Psychology, DIW Research Director)

Elke Holst (Gender Studies, DIW Research Director)

Frauke Kreuter (Survey Methodology, DIW Research Professor)

Martin Kroh (Political Science and Survey Methodology)

Frieder R. Lang (Psychology, DIW Research Professor)

Henning Lohmann (Sociology, DIW Research Professor)

Jörg-Peter Schräpler (Survey Methodology, DIW Research Professor)

Thomas Siedler (Empirical Economics)

C. Katharina Spieß (Empirical Economics and Educational Science)

ISSN: 1864-6689 (online)

German Socio-Economic Panel Study (SOEP)

DIW Berlin

Mohrenstrasse 58

10117 Berlin, Germany

Contact: Uta Rahmann | soeppapers@diw.de 


\title{
Working Paper \\ Measuring Fuel Poverty \\ General Considerations and Application to German Household Data
}

\author{
Peter Heindl ${ }^{1}$
}

\begin{abstract}
Fuel poverty measurement consists of two independent parts: firstly, the definition of an adequate fuel poverty line, and secondly, techniques to measure fuel poverty. This paper reviews options for the definition of fuel poverty lines and techniques for fuel poverty measurement. Based on household data from Germany, figures that would result from different fuel poverty lines are derived. Different fuel poverty lines yield highly different results with respect to which households are identified as fuel poor. Thus, the choice of the fuel poverty line matters decisively for the resulting assessment. Options for fuel poverty measurement and subgroup comparison are discussed.
\end{abstract}

\section{Das Wichtigste in Kürze}

Energiearmut könnte ein zunehmend ernstes Problem darstellen, falls die realen Preise für Energie marktbedingt oder durch politische Maßnahmen zur Treibhausgasvermeidung rasch ansteigen. Die Messung von Energiearmut beruht im Wesentlichen auf zwei weitgehend voneinander unabhängigen Bestandteilen. Zum einen muss eine angemessene Energiearmutsgrenze definiert werden. Dies ist eine weitgehend normative Frage. Zum anderen müssen passende Methoden zur Messung von Energiearmut (auf Basis einer Energiearmutsgrenze) ausgewählt werden. In diesem Arbeitspapier werden eine Reihe von Energiearmutsgrenzen auf Basis der bestehenden Literatur diskutiert und auf ihre Eignung zur Anwendung auf den Fall Deutschlands hin überprüft. Zudem werden Techniken zur Messung von Energiearmut vorgeschlagen. Auf Basis deutscher Haushaltsmikrodaten aus dem Sozio-ökonomischen Panel (SOEP) werden Ergebnisse für verschiedene Energiearmutsgrenzen generiert und gegeneinander abgewogen. Wie sich zeigt, kommt es bei der Anwendung verschiedener Energiearmutsgrenzen teilweise zu wesentlichen Unterschieden in der resultierenden Bewertung von Energiearmut. Die Wahl der Energiearmutsgrenze beeinflusst daher maßgeblich die resultierende Bewertung des Ausmaßes an Energiearmut und sollte mit Bedacht gewählt werden. Auch verschiedene Messtechniken können zu teils sehr unterschiedlichen Ergebnissen hinsichtlich der Armutsbewertung führen. Daher werden Möglichkeiten zur Messung von Energiearmut insbesondere mit Hinblick auf einen Vergleich verschiedener Haushaltstypen aufgezeigt und auf die verfügbaren Haushaltsmikrodaten angewendet.

Keywords: Fuel Poverty; Energy Poverty; Poverty Measurement; Energiearmut; Germany

JEL-Classification: I32; Q28; Q48

\footnotetext{
${ }^{1}$ Heindl: Centre for European Economic Research (ZEW), L7, 1, D-68161 Mannheim, Germany (heindl@zew.de). Financial Support of the German Ministry of Education and Research (BMBF) in the project "Sozialpolitische Konsequenzen der Energiewende in Deutschland (SOKO Energiewende)”, grant number: 01UN1204A, is gratefully acknowledged. I like to thank Florens Flues and Holger Stichnoth for helpful discussions. I also like to thank the team that provides the SOEP database.
} 


\section{Introduction}

Direct residential consumption of energy, i.e. electricity, space heating and water heating, is an important part of overall household $(\mathrm{HH})$ consumption and contributes to well-being and social participation, e.g. by supplying comfortable warmth or options to use appliances at home, like TV sets, computers, stoves, washing machines, and others. Residential energy demand is dependent on a number of variables, such as income, prices, preferences, and attitudes (Kriström, 2008). The elasticity of demand is lower in the short run compared to the long run, which is due to "fixed assets” and limited options for increases in energy efficiency in the short run (Kriström, 2013). It was shown for Dutch households that the demand for space heating is highly dependent on the characteristics of dwellings, while electricity consumption is mostly dependent on household characteristics and household composition (Brounen et al., 2012). For Dutch households it was also shown that changes in energy consumption are highly dependent on psychological variables rather than on household composition (Abrahamse and Steg, 2009). For the case of Norway, it was found that the price sensitivity of residential energy consumption is higher for high-income households compared to low-income households (Nesbakken, 1999). For the case of Germany, it was shown that increases of energy efficiency in space heating are more pronounced in owner-occupied dwellings compared to rented dwellings (Rehdanz, 2007). The income of house owners is an important driver for energy retrofits in Germany, where house owners with lower incomes are less likely to invest in energy retrofits (Achtnicht and Madlener, 2012). Similar results were obtained for the case of Great Britain, where owner occupied households and tenant households show different sensitivity to changes in fuel prices (Meier and Rehdanz, 2010). Overall, income (Nguyen-Van, 2010) ${ }^{2}$ and prices (Reiss and White, 2008) determine residential energy demand and the price elasticity of demand (Reiss and White, 2005), but also human behaviour, or, more general, household preferences matter decisively (Kriström, 2008; Reiss and White, 2008). Taking “non-

\footnotetext{
${ }^{2}$ Income affects overall energy consumption with increasing demand for increasing incomes (Nguyen-Van, 2010). On the household level, electricity demand is dependent on the household's appliances stock which is dependent on income according to Reiss and White (2005).
} 
price” behavioural aspects of energy consumption in the design of energy efficiency policies into account can have a strong impact on policy effectiveness (Allcott and Mullainathan, 2010).

Increasing energy prices can be a threat for households with lower income. Price increases may result from increases in the real prices of fossil fuels, but also from policies for greenhouse gas reduction, such as green taxes, subsidies, or costs of renewable energy promotion. The timeline in which increases in energy prices occur might be of particular importance with respect to fuel poverty because households need some time to adapt to price changes by increases in energy efficiency. This is reflected in a relatively low short-term price elasticity compared to the longer term (Kriström, 2013). In addition, households with lower income might find it hard to increase energy efficiency of the household because of budget constraints, e.g. to replace appliances or move to more energy-efficient dwellings. Taking the pace of price changes for energy services into account, the impact of environmentally motivated policies on energy prices might be of particular importance with respect to fuel poverty, either as a temporary or permanent issue, depending on the actual policy.

A case in point is the German energy transition. The federal government of Germany has defined a number of policy targets that aim to reduce greenhouse gas emissions in Germany by 40 per cent until $2020^{3}$. A key policy is the German renewable energy feed-in tariff scheme (ErneuerbareEnergien-Gesetz, EEG) that offers subsidies for renewable energy carriers. While the scheme is very effective in promoting renewable energy ${ }^{4}$, the resulting costs are considerable. Costs for renewable energy promotion are partly born by households and are directly passed through to the electricity bills. The costs for renewable energy promotion per consumed kilowatt hour (kWh) of electricity for households have grown from EUR cent 0.41 in 2003 to EUR cent 5.277 in 2013. A three-person household consuming 3,500 kWh of electricity in 2013 faces costs of about EUR 185

\footnotetext{
${ }^{3}$ Please see BMWi (2012) and IEA (2013) for details on the German energy transition.

${ }^{4}$ The share of renewable energy carriers in gross electricity production in Germany was 20.3 per cent in 2011 and 12.1 per cent in final energy consumption (BMWi, 2012).
} 
in 2013 that directly go back to renewable energy promotion. Costs are expected to increase further if the policy targets of the energy transition shall be achieved. Containment of costs for the energy transition has become an increasingly important issue (IEA, 2013), inter alia, because there are tight links between GHG mitigation policies and poverty alleviation or avoidance (Ürge-Vorsatz and Tirado Herrero, 2012) ${ }^{5}$ and because inequality and poverty are still an issue even in many developed countries (OECD, 2011), including Germany (BMAS, 2013). The strong increase in electricity prices in Germany has led to a discussion on potential social drawbacks of the energy transition, e.g. by fuel poverty or "Energiearmut”, which has not been an issue in the public debate so far $^{6}$.

The aim of this paper is not to generate some particular figures on fuel poverty in Germany. Its aim is to provide a conceptual discussion on how fuel poverty could be defined and measured based on the literature and previous experiences, e.g. from the United Kingdom. While the term fuel poverty is used throughout this paper, it does not imply that a household is actual fuel poor or poor in general. The term should be interpreted in the sense that a household identified as fuel poor is potentially strongly impacted by the costs of energy or alternatively can be regarded as a vulnerable energy consumer in accordance to the EU Commission's definition in the directives for the harmonisation of European energy markets (CEER, 2012; EU, 2009a, 2009b).

The discussion on options for fuel poverty measurement consists of two steps. First, a fuel poverty line needs to be defined. Since any fuel poverty line is arbitrary in some sense, there is no technique available to identify an "optimal” fuel poverty line. The definition of a fuel poverty line is subject to public discussion on which poverty line is seen as reasonable and can be agreed on by the public. It might, however, be acceptable to require a fuel poverty line to identify those households that are affected the most by the costs for energy services. As an application on household microdata from

\footnotetext{
${ }^{5}$ On a global scale, this argument is related to the environmental Kuznets curve discussion.

${ }^{6}$ A number of contributions to the fuel poverty discussion in Germany were published in early 2013, such as Goldhammer, Mans and Rivera, (2013). In Austria, the national energy regulation authority E-control contributed to the discussion (E-Control, 2013).
} 
the German socio-economic panel (SOEP) will show, fuel poverty lines differ strongly in terms of which households are identified as fuel poor. A second aspect is related to the actual measurement of fuel poverty (once a fuel poverty line has been agreed). Based on the work of Watts (1968), Sen (1976), Kakwani (1980), Foster, Greer and Thorbecke (1984) and Atkinson (1987), there are well established concepts available that allow an assessment of poverty and the depth of poverty as well. Based on German microdata, a proposal is made regarding how fuel poverty could be measured in order to identify subgroups of households which are most vulnerable to increases in energy prices.

The paper is organised as follows. Section 2 provides a discussion on fuel poverty measurement in general and reviews the most important techniques available for fuel poverty measurement. Section 3 considers a number of potential fuel poverty lines based on the literature. In Section 4 different fuel poverty lines are applied to German household microdata in order to illustrate which types of households are identified as fuel poor by the different poverty lines, including an example of how fuel poverty could be measured in order to identify most vulnerable households or subgroups in the population. Section 5 concludes.

\section{Concepts of Poverty Measurement}

Poverty measurement in developed countries is often based on a poverty line that is determined relative to the median income of the overall population. In many countries, the poverty line is set to equal 60\% of median income, which was 952 EUR in Germany in 2010 (BMAS, 2013, p. 461). The World Bank proposed the absolute poverty line of one Dollar per day for least developed countries in its 1990 World Development Report ${ }^{7}$. The poverty line was updated to 1.25 Dollar in 2005 purchasing power parity. Although the 1.25 Dollar poverty line is an absolute one, it can be drawn from the national poverty lines of least developed countries that rely on considerations of basic needs and aspects of relative poverty as well (Ravallion et al., 2009, 1991).

\footnotetext{
${ }^{7}$ For a discussion on the applicability and adequacy of a unique global poverty line, such as the Dollar-per-day line, see for example Banerjee and Duflo (2007).
} 
Poverty measurement is sensitive to the choice of the poverty line that determines which persons or households are regarded as poor but also to the choice of poverty measure. The most intuitive poverty measure is the headcount-ratio, which equals the share of persons or households that fall below the poverty line relative to the overall population. While the headcount-ratio is an easy-tointerpret measure, it says nothing about the distribution of incomes below the poverty line. The poverty gap index takes the distance of incomes below the poverty line to the poverty line into account and therefore gives an indication of how much persons or households fall short of adequate income. Similar to the headcount-ratio, the poverty gap index gives limited information on the severity or depth of poverty within the group of the poor.

Sen (1976) proposed an axiomatic approach to poverty measurement with the propositions that given other things a) a reduction of income of a person below the poverty line must increase the poverty measure (monotonicity axiom) and b) a pure transfer of income from a person below the poverty line to anyone who is richer must increase the poverty measure (transfer axiom) (Sen 1976, p.219). The transfer-sensitivity axiom further states that a poverty measure should be sensitive to transfers that take place between persons or households below the poverty line (Kakwani, 1980). It is possible to construct income transfers that leave the headcount-ratio and the poverty gap index unchanged (or even decrease the headcount-ratio) while the transfers violate the axioms proposed by Sen (1976) and Kakwani (1980). This includes cases where the headcount-ratio decreases, while the income of one or more persons below the poverty line is decreased, including the possibility that one or more persons are put into hardship ${ }^{8}$.

Foster, Greer and Thorbecke (1984) (FGT) proposed a class of poverty measures in which the headcount-ratio and the poverty gap index are nested, but can be parameterised so that it gives higher weights to lower incomes below the poverty line, is decomposable over subgroups of a

\footnotetext{
${ }^{8}$ See Coudouel, Hentschel and Wodon (2002) for a broader, mostly non-technical discussion on the application of poverty measures.
} 
population (i.e. is additively decomposable with population share weights), and is one of the most comprehensive aggregated poverty measures (Zheng, 1997). The FGT poverty measure is given by

$$
P_{\alpha}=\frac{1}{N} \sum_{i=1}^{q}\left(\frac{G_{i}}{z}\right)^{\alpha},
$$

where $z$ is the poverty line, $G_{i}$ is the poverty gap of person or household $i$, and $N$ is the total number of the population with $q$ persons or households falling below the poverty line. Parameter $\alpha$ weights incomes, with higher $\alpha$ giving higher weights to lower incomes. The poverty gap takes into account incomes below the poverty line $y_{i}<z$ so that

$$
G_{i}=\left(z-y_{i}\right) \text { for } y_{i}<z
$$

For $\alpha=0, P_{\alpha}$ equals the headcount-ratio, for $\alpha=1, P_{\alpha}$ equals the poverty gap index, and for $\alpha>1$, incomes (below the poverty gap) are weighted with increasing weights for lower incomes as $\alpha$ increases. As noted by Foster, Greer and Thorbecke (1984, p. 763) the FGT measure approaches a "Rawlsian” measure for $\alpha \rightarrow \infty$, which focuses on the position of the poorest household.

Since fuel poverty is a special aspect of poverty, fuel poverty measurement should be related to general poverty measurement in the sense that the interference of both types of poverty can be explained and compared. Fuel poverty measures should further satisfy the same axioms as general poverty measures. Most importantly, this implies that in addition to $P_{0}$ or $P_{1}$, measures $P_{\alpha>1}$ can be applied to account for the transfer axiom (Foster, Greer and Thorbecke, 1984. p. 763) originally proposed by Sen (1976). As proposed by Foster, Greer and Thorbecke (1984, p. 764), FGT class poverty measures of different order can be applied to compare subgroups in the population. This might be of particular appeal in the case of fuel poverty in order to identify groups of most 
vulnerable energy consumers ${ }^{9}$. Several types of fuel poverty lines or hybrid fuel and income poverty lines were proposed in the literature or applied in policy evaluation. The following section discusses options for the choice of the fuel poverty line.

\section{Fuel Poverty Definitions}

Just as the $60 \%$ median income poverty line definition, fuel poverty lines are arbitrary in some aspects. Proposed definitions differ strongly in terms of robustness to changes in energy prices, incomes and with regard to data requirements. They also differ in their ability to capture differences in household energy needs that arise from different household sizes, income, or composition. Families with children, for example, require on average more living space than single persons or couples without children, which will increase the need for and the costs of space heating and electricity. The energy efficiency of dwellings might correlate with the rent and overall housing costs and influences the expenditures for space heating or cooling, but is not perfectly observable. This is also an argument to use income after housing costs (AHC) to assess energy poverty (Moore, 2012). Apart from the question how to define a fuel poverty line, there are also a number of options how to measure income and the costs of energy services, e.g. whether to equalise income or fuel costs, and how to capture the requirements of specific subgroups, such as families with children, lone parents, or elder people in an appropriate way. Several fuel poverty definitions have been proposed and used in the literature. Some definitions focus on fuel expenditures of households relative to income, such as the 10 per cent threshold, or the two times median/mean expenditure share poverty line. Other possible definitions could focus exclusively on expenditures for energy services of households relative to the median or mean expenditure of the overall population. Some approaches focus on the basic needs of different types of households based on minimum income standards (MIS) or on households with high (fuel) costs and low income (HCLI).

\footnotetext{
${ }^{9}$ Adequate protection of vulnerable consumers is demanded by the Directives of the European Commission concerning rules for the internal market in electricity (2009/72/EC) and gas (2009/73/EC).
} 
In the UK, a 10\% threshold of energy related expenditures relative to available income has been used to assess fuel poverty. The concept has also been applied to the case of Ireland (Healy and Clinch, 2004). According to the UK Fuel Poverty Strategy 2001, whose aim is to eliminate fuel poverty by 2016, a household is defined as fuel poor if it "would need to spend at least $10 \%$ of its income in order to heat the house to an acceptable level of warmth”. Apart from space heating, other energy services such as water heating, lights, appliances, and cooking are considered (Moore, 2012, p. 20). Income is measured based on full income before housing costs (BHC), including housing benefits and on a non-equivalised scale, i.e. not adjusted for household size and composition (Hills, 2012, pp. 29-30; Moore, 2012). Fuel Poverty in England is assessed based on data from the English Housing Survey and modelled utility bills of households. The 10 per cent threshold has been criticised as inappropriate since it relies on observations made more than twenty years ago by Boardman (1991) ${ }^{10}$ and is highly sensitive to changes in energy prices (Moore, 2012). The UK government intends to change the official fuel poverty line and it was recommended to move away from the 10 per cent threshold by Hills (2012). Based on the 10 per cent threshold, 15 per cent of households in England where identified as fuel poor in 2011, 25 per cent in Scotland, 29 per cent in Wales, and 42 per cent in Northern Ireland (Department of Energy and Climate Change, 2013). Instead of the 10 per cent threshold, alternative shares of expenditures on energy services could be defined as fuel poverty line.

Originally, the 10 per cent threshold represented the share of income spent on fuel services by the poorest 30 per cent of households in the UK and about twice the median of expenditure on fuel services relative to the overall sample population in Boardman (1991) and according to Moore (2012). Earlier works that date back to the 1970s also applied the two times median concept (Liddell et al., 2012). The twice the median concept identifies households with unusually high expenditures on energy services. Since the median divides the distribution of expenditures on energy services in two parts, with 50 per cent of households having higher (lower) expenditures

\footnotetext{
${ }^{10}$ See Liddell, Morris, McKenzie, \& Rae, (2012) for a review on fuel poverty in the United Kingdom.
} 
than the median, the concept is relatively robust to extremely low or high observed values of expenditures in a sample. In this paper, the concept is applied to expenditures on energy services and the share of expenditures relative to income for comparison.

In a working paper of the EU Commission, the fuel poverty line was set equal to two times the average fuel expenditure share (relative to income) of all households in the sample population (European Commission, 2010). The concept is similar to the two times median approach. A major disadvantage of the two times average approach is that the average (arithmetic mean) is more sensitive to extreme values in a distribution. A clear advantage is that mean values are often available for aggregated data on energy-related expenditures of households, while the median is not. The concept is applied to expenditures on energy services and the share of expenditures relative to income for comparison as in the case of the median approach described above.

In some countries, such as Norway or Sweden, there are budget standards, which are defined to identify assistance needs for (poor) households (Bradshaw et al., 2008, p. 2). A minimum income standard (MIS) for Britain was proposed by Bradshaw et al. (2008). The MIS is defined as “having what you need in order to have the opportunities and choices necessary to participate in society" (Bradshaw et al., 2008, p. 1). Needs for different types of households were assessed based on "Blending” in Bradshaw et al. (2008), which takes into account the views of experts and the public in deriving and assessing income standards for different types of households and different types of goods and services. The MIS proposed for Britain augments the standard $60 \%$ of median income poverty assessment. As shown in Bradshaw et al. (2008), the proposed MIS matches the $60 \%$ of median definition well, but also casts light on the needs of several subgroups, such as families with children, which have higher needs relative to other households. According to Moore (2012), income standards could be used to assess fuel poverty. A household would be subject to fuel poverty if the available income after housing and fuel costs is insufficient to meet the minimum income standard. While the MIS takes several subgroups of the population into account, it might fail to identify the 
needs of individual households in certain situations. The needs of a family with children might differ significantly depending on the age of a child, e.g. because of costs for childcare or tuition fees. Also, for elder people, the costs for medical and healthcare will highly depend on the health status of a person which can change unexpectedly. For the case of Germany, social benefit rates (based on German law Sozialgesetzbuch II, also SGB II ${ }^{11}$ ) could be interpreted as a MIS. Although SGB II rates differ conceptually from MIS as defined by Bradshaw et al. (2008), they represent what is regarded as reasonable income under basic security. From the perspective of public economics, the SGB II rates could represent a MIS since labour supply would presumably be zero for households whose income from labour minus housing costs and necessary expenses for energy services falls below SGB II rates ${ }^{12}$. In this case, fuel poverty could, on the margin, be a motivation for households with lower (labour) income to decrease labour supply and receive SGB II benefits under which the cost for space heating and in some cases certain expenditures for electricity are taken over by the welfare agency.

A report commissioned by the British Department of Energy and Climate Change reviewed the definition of fuel poverty in the UK with a strong focus on how to measure fuel poverty (Hills, 2012). The Hills Report made the recommendation that "the Government should change its approach to fuel poverty measurement away from the current '10 per cent' ratio indicator" (Hills, 2012, p. 8). In the report, a new approach was proposed. It was suggested that a household should be regarded as fuel poor if it faces fuel costs above the median level and is left (after expenditures on all energy services) with a remaining income below the poverty line of $60 \%$ of median income

\footnotetext{
${ }^{11}$ Benefit rates under SGBII are defined based on statistical data on income and expenditure in Germany as defined in the law Gesetz zur Ermittlung der Regelbedarfe nach § 28 des Zwölften Buches Sozialgesetzbuch (RegelbedarfsErmittlungsgesetz - RBEG). All essential expenditure categories must be considered in a transparent way in the process of SGBII rate definition according to the German High Court (BVerfG, 1 BvL 1/09 vom 9.2.2010, Absatz-Nr. (1 220)).

${ }^{12}$ Under SGB II social security, housing costs and expenses for space heating and partly for water heating are directly taken over by the welfare agency. Thus, costs for those energy services could influence labour supply of households with incomes marginally above social benefit rates.
} 
after housing costs. It was further proposed to equivalise income (based on the OECD scale) as well as fuel costs (based on a specific fuel cost scale, see Table 1).

Table 1: Fuel cost equivalence scale as proposed by (Hills, 2012, p. 52)

\section{Household type}

Couple with dependent children

Couple without dependent children

Lone parent

Single person

Other multi-person household

Source: Hills (2012)
Equivalence factor

\subsection{5}

1.00

0.94

0.82

1.07

The definitions of fuel poverty lines discussed above differ in many aspects. While the 10 per cent, the two times median, and the two times average approach establish a pure fuel poverty line, the MIS and HCLI are based on an income poverty line after expenditures for energy services are taken into account. Taking equivalised income into account offers the possibility to capture the requirements of different household types more adequately relative to non-equivalised income or if fuel poverty lines that ignore household incomes are used. Considering income after housing costs could further capture some aspects of energy efficiency of buildings, but incurs the risk of overweighting under-occupied dwellings or households with preferences (i.e. a willingness to pay) for larger dwellings. Table 2 summarises the most important properties of the different fuel poverty lines.

Table 2: Overview of fuel poverty lines and their properties

\begin{tabular}{|c|c|c|c|}
\hline Type & Measurement & Properties & Equiv. Income \\
\hline $10 \%$ & $\begin{array}{l}\text { Expenditure on energy services } \\
\text { greater or equal to } 10 \% \text { of } \\
\text { income (or any other share). }\end{array}$ & $\begin{array}{l}\text { HH specific poverty line } \\
\text { dependent on HH income. } \\
\text { Fuel poverty line. }\end{array}$ & No (optional) \\
\hline $\begin{array}{l}2 \mathrm{x} \\
\text { median } \\
\text { energy } \\
\text { exp. }\end{array}$ & $\begin{array}{l}\text { Expenditure on energy services } \\
\text { greater or equal to } 2 \mathrm{x} \text { median } \\
\text { expenditure (or any other } \\
\text { factor). }\end{array}$ & $\begin{array}{l}\text { Unique poverty line within } \\
\text { sample, not dependent on } \\
\text { income. Fuel poverty line. }\end{array}$ & Not applicable \\
\hline $2 \mathrm{x}$ & Share of energy expenditures & Unique poverty line within & Yes (optional \\
\hline
\end{tabular}




\begin{tabular}{l|l|l|l}
$\begin{array}{l}\text { median } \\
\text { share }\end{array}$ & $\begin{array}{l}\text { relative to income greater or } \\
\text { equal to 2x median share of } \\
\text { expenditures in the sample }\end{array}$ & $\begin{array}{l}\text { sample as ratio of median } \\
\text { expenditures and income }\end{array}$ & no) \\
$\begin{array}{l}2 \mathrm{x} \\
\text { average } \\
\text { energy } \\
\text { exp. }\end{array}$ & $\begin{array}{l}\text { Expenditure on energy services } \\
\text { greater or equal to 2x average } \\
\text { expenditure (or any other } \\
\text { factor). }\end{array}$ & $\begin{array}{l}\text { Unique poverty line within } \\
\text { sample not dependent on } \\
\text { income fuel poverty line. }\end{array}$ & Not applicable \\
$\begin{array}{l}\text { 2x } \\
\text { average } \\
\text { share }\end{array}$ & $\begin{array}{l}\text { Share of energy expenditures } \\
\text { relative to income greater or } \\
\text { equal to 2x mean share of } \\
\text { expenditures in the sample }\end{array}$ & $\begin{array}{l}\text { Unique poverty line within } \\
\text { sample as ratio of mean } \\
\text { expenditures and income }\end{array}$ & Yes (optional \\
no)
\end{tabular}

\section{Fuel Poverty in Germany: A Comparison of Poverty Lines}

In this section, poverty measures are calculated for the case of Germany based on comprehensive household data from the German socio-economic panel (SOEP) and under consideration of different fuel poverty lines. The aim of this section is not to present some particular figures on fuel poverty in Germany, but to discuss the applicability of different fuel poverty lines. The analysis is based on German household survey data from 2011, the GSOEP28 dataset. The data reflect the situation in the year 2010. Since the SOEP dataset was used for the official poverty line assessment in Germany (BMAS, 2013) and contains a large number of socio-economic variables, the data nicely match the research question. After a brief data description, different fuel poverty lines are tested against each 
other, followed by a proposal how to identify households which are most vulnerable to fuel poverty or increasing energy costs in general.

\subsection{Data Description}

For some fuel poverty measures, e.g. the two time median expenditure measure, the only information needed is household expenditure on energy services. Other measures, such as the MIS or low income/high cost measure, require information on housing costs and income as well. To be consistent in comparing fuel poverty measures, a subsample of the GSOEP28 dataset is used for which all required data are available for 2011 (Wagner et al., 2007). ${ }^{13}$ The original full sample of n=12,290 observations in 2011 collapses to $n=10,193$ observations for which available household income, costs for electricity, space heating, and water heating as well as housing costs are jointly available. Since costs for electricity were not available for 2,560 households that own property, their costs were generated by imputation (based on the predicted values of an OLS regression, see Appendix 3). Equivalised household incomes are generated based on the (new) OECD equivalence scale that weights the first adult in a household by 1.0, each additional person in the household of age 15 or higher by 0.5 , and each child aged 14 years or less by $0.3^{14}$. The scale was first proposed by Hagenaars et al. (1994) and was adapted by Eurostat in the late 1990s. Equivalisation of household incomes is the standard procedure to account for different household sizes and compositions and is used by the German statistical office. After equivalised income was generated, the mean equivalised income in the full sample is EUR 1,586, with $60 \%$ of the mean income (the official poverty line) at EUR 952. The income distribution in the subsample of $n=10,193$ is similar to the original one with a mean income of EUR 1,556 and $60 \%$ of the mean equal to 934 EUR. Costs for energy services consist of expenditures for electricity, heat, and water heating. Available income and equivalised income are distinguished by income before housing costs (BHC) and

\footnotetext{
${ }^{13}$ Socio-Economic Panel (SOEP), data for years 1984-2011, version 28, SOEP, 2012, doi: 10.5684/soep.v28.

${ }^{14}$ Equivalised income or equivalised disposable income is generated by dividing the actual disposable income of a household by the modified or new OECD scale factor. The scale factor of a single-adult $\mathrm{HH}$ is 1 , for a two-adult $\mathrm{HH}$, 1.5, for two-adult and one-child $\mathrm{HH}, 1.8$, etc.
} 
income after housing costs (AHC). Housing costs consist of mortgage or home loan interest, repayments, and running additional charges for property owners and rents and additional charges for tenants. An additional set of variables is available, which are not needed to calculate fuel poverty measures, but can be used to identify subgroups of households. This includes the size of dwellings (square meters), the number of occupied rooms, the number of persons in the household, the type of household (single, couple, couple with children, lone parent, and others), the quality of dwelling (e.g. if it needs refurbishment), the age of buildings, further information on dwellings (e.g. if a balcony is available), and information whether a dwelling is let with rebate. The SOEP dataset also provides population share weights, which are used to weight the sample so that it properly reflects the overall population in Germany. Summary statistics are reported in Table 9.

As Figure 1 shows, about 25 per cent of households in the sample had expenditures for all energy services of more than 10 per cent of non-equivalised household income BHC. The mean expenditure share in 2011 was 8.2 per cent. Mean expenditure for electricity was EUR 66 or 3.2 per cent of non-equivalised income BHC. Mean expenditure for space heating was EUR 102 or 5.0 per cent of non-equivalised income BHC. The figures differ not too much from those in Neuhoff et al. (2012, 2013), where different data were used ${ }^{15}$.

\footnotetext{
${ }^{15}$ Neuhoff et al. (2012, 2013) used German household data from the Federal Statistical Office (DEStatis), namely the "Einkommens- und Verbrauchsstichprobe".
} 


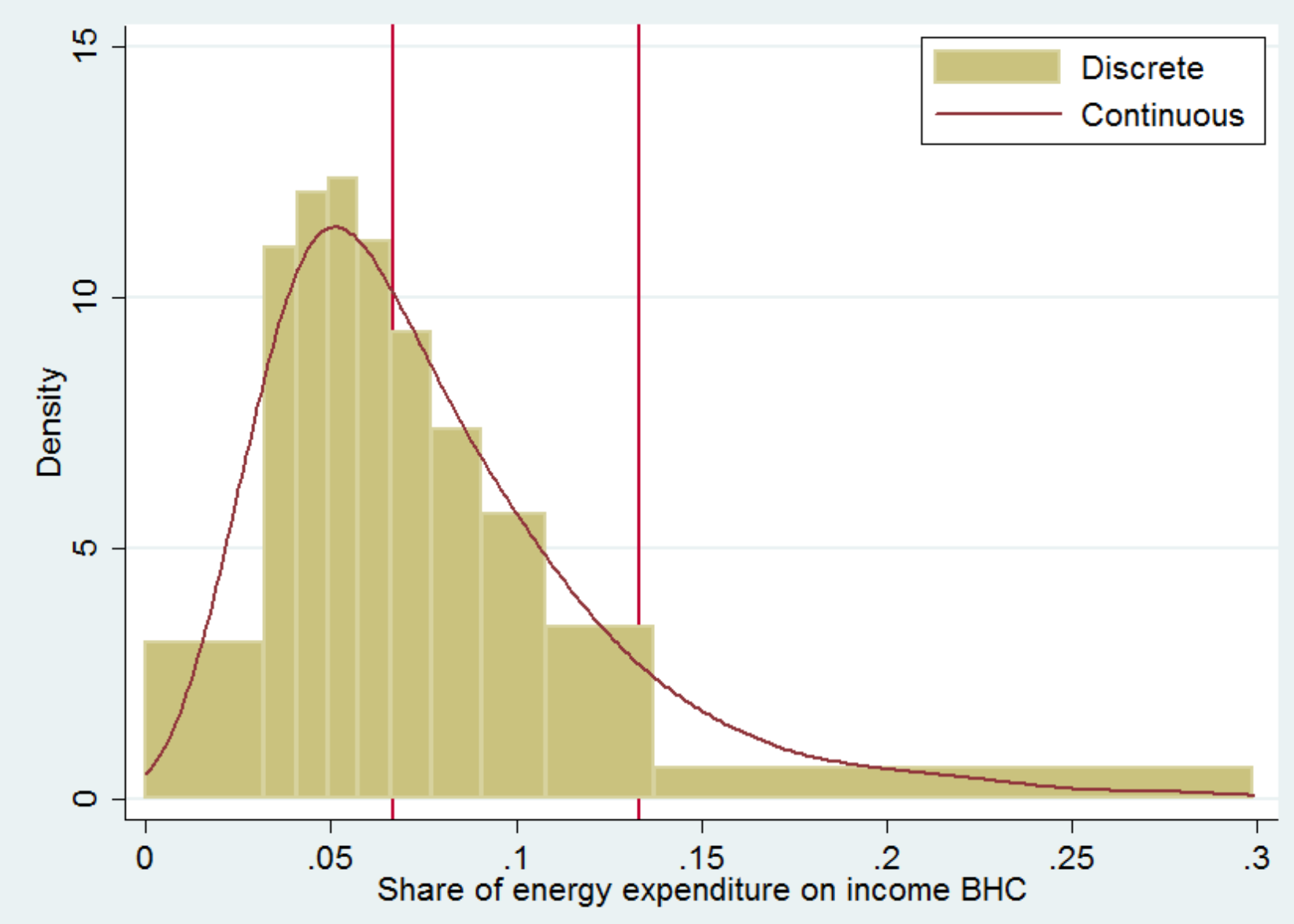

Figure 1: Estimated density of the share of expenditures for all energy services relative to nonequivalised household income in the sample (x-axis). Each discrete bin represents $10 \%$ of the distribution. In addition, a continuous estimated density plot is added to the figure. The vertical lines represent the median and two times the median share of expenditure. The density (y-axis) has no direct interpretation. It can be interpreted as the frequency of observed expenditure shares in the sample. The integral over the density function equals one.

A joint look at equivalised income and expenditures for energy services reveals that the share a household in the sample spends on all energy services strongly depends on income. The poorest 10 per cent of households need to spend 19 per cent of equivalised income on energy services in median, while the richest 10 per cent of households have a cost share of 4.8 per cent in median. Energy consumption and energy expenditures do not increase at the same rate as equivalised household income. This gives a first indication that fuel poverty might be a predominant issue amongst households with low income or with energy needs above average, such as families, lone parents, or elder people. Average equivalised incomes and expenditure on all energy services are displayed in Figure 2 for all households in the sample and several subgroups. 


\subsection{A Comparison of Fuel Poverty Lines}

Table 3 shows the results of a fuel poverty assessment based on German data from the SOEP 2011. Eight fuel poverty lines are considered. The $10 \%$ poverty line, where a household is identified as fuel poor if its expenditures on all energy services (space and water heating and electricity) ${ }^{16}$ are higher or equal to ten per cent of non-equivalised household income. A similar fuel poverty line (based on modelled bills) has been used for the assessment of fuel poverty in the UK (Moore, 2012). The two times median expenditure poverty line considers a household as fuel poor if its expenditures are equal to or above the two times median expenditure in the sample. The two times mean expenditure poverty line takes the same approach with average expenditures in the sample. The two times median share of energy expenditure relative to income, that has been previously applied in the UK (Liddell et al., 2012), considers the share of expenditures relative to income rather than absolute expenditures. Also a two times mean expenditure share poverty line is considered, following a working paper of the EU Commission (European Commission, 2010). Both the median and mean share concepts are applied using equivalised incomes in the application below. For the MIS poverty line, German welfare rates (SGBII rates) are taken as a minimum income standard. Although SGB II rates are no MIS as defined by Bradshaw et al. (2008), they reflect the actual least income available for households in Germany. SGB II rates are allocated depending on household composition. SGB II rates can therefore be interpreted as an available minimum income on an equivalised scale and could potentially be used as a focal point for fuel poverty assessments. The scale implied by SGB II rates is different from the new OECD scale. Thus, both approaches are only comparable to some extent (see Appendix 1 for details). The high cost/low income (HCLI) approach is motivated by Hills (2012). The poverty line is defined by two conditions. Firstly, a household must have expenditures on all energy services above the mean to be

\footnotetext{
${ }^{16}$ While (Neuhoff et al., 2013, 2012) focus on electricity prices, it seems to be appropriate to assess fuel poverty based on expenses on all energy services to be consistent over time and to capture all changes in prices, including fossil fuels and policy-driven price changes. Furthermore, space heating represents a basic need for German households for several months of the year and should thus be included in every fuel poverty assessments.
} 
considered as potentially fuel poor. Secondly, a household qualifies as fuel poor if it is left with a residual income (after expenditures on energy services) below the official poverty line. The approach can be applied before housing costs (BHC) and after housing costs (AHC). The poverty line must be adjusted accordingly and is set to EUR 952 before housing costs (BMAS, 2013) and to EUR 775 after housing costs based on SOEP data in 2011. Hills (2012) also suggested to equivalise energy expenditures according to household type (see Table 1). Expenditures on energy services are not equivalised in this paper to avoid an overweighting of specific household types and to allow for comparison with the official income poverty line.

As shown in Table 3, the share of households potentially subject to fuel poverty is rather high (25.1\%) if the 10 per cent poverty line is applied. The figure is higher compared to England, where $15 \%$ of households fell under the 10 per cent threshold in 2011, similar to Scotland (25\%), but lower compared to Wales (29\%) and Northern Ireland (42\%) ${ }^{17}$ (Department of Energy and Climate Change, 2013, p. 19). The two times median expenditure and two times mean expenditure approach yield relatively low shares of fuel poor ( $4.6 \%$ and $2.9 \%)$. These poverty lines clearly fail to capture poorer households. Average equivalised income in the group of fuel poor is very high when using these poverty lines, while the share of households that fall below the official poverty line is low. In contrast, the 2x median and mean expenditure share poverty lines yield higher shares of fuel poor (11.2\% and 4.9\%). The MIS poverty line identifies $8.8 \%$ of households as subject to fuel poverty. These households have the lowest average equivalised income (EUR 721) compared to other poverty lines. About 90 per cent of fuel poor households under the MIS also fall below the income poverty line. The HCLI BHC poverty line identifies 10.5 per cent of households as fuel poor, with an average equivalised household income of EUR 907, which is close to the income poverty line of 952 EUR. 52 per cent of households that were identified as fuel poor by the HCLI BHC also fall

\footnotetext{
${ }^{17}$ The results for the UK are based on modeled bills, while the results for Germany are based on household survey data from the SOEP. EUROSTAT data show that prices for gas were about the same in Germany and the UK in 2010 and 2011 (data nrg_pc_202), but electricity prices in Germany were about 10 EUR cent per kWh higher in Germany compared to the UK for households consuming 2,500 to 5,000 kWh of electricity (data nrg_pc_204).
} 
under the official poverty line and fuel poor households have particularly high shares of expenditures on energy services relative to income with mean 26.3 per cent. The HCLI AHC poverty line identifies 12.6 per cent of households as fuel poor. For the case of England, the HILC indicator identified a share of about 12 per cent of fuel poor (Department of Energy and Climate Change, 2013, p. 21) based on a slightly different methodology (equivalised energy expenditure and different income poverty line). Similar to the case of Germany, the HILC approach delivered a lower share of fuel poor in the case of England compared to the 10 per cent approach. Average equivalised incomes and expenditures on all energy services are displayed in Figure 2, where different fuel poverty lines are compared.

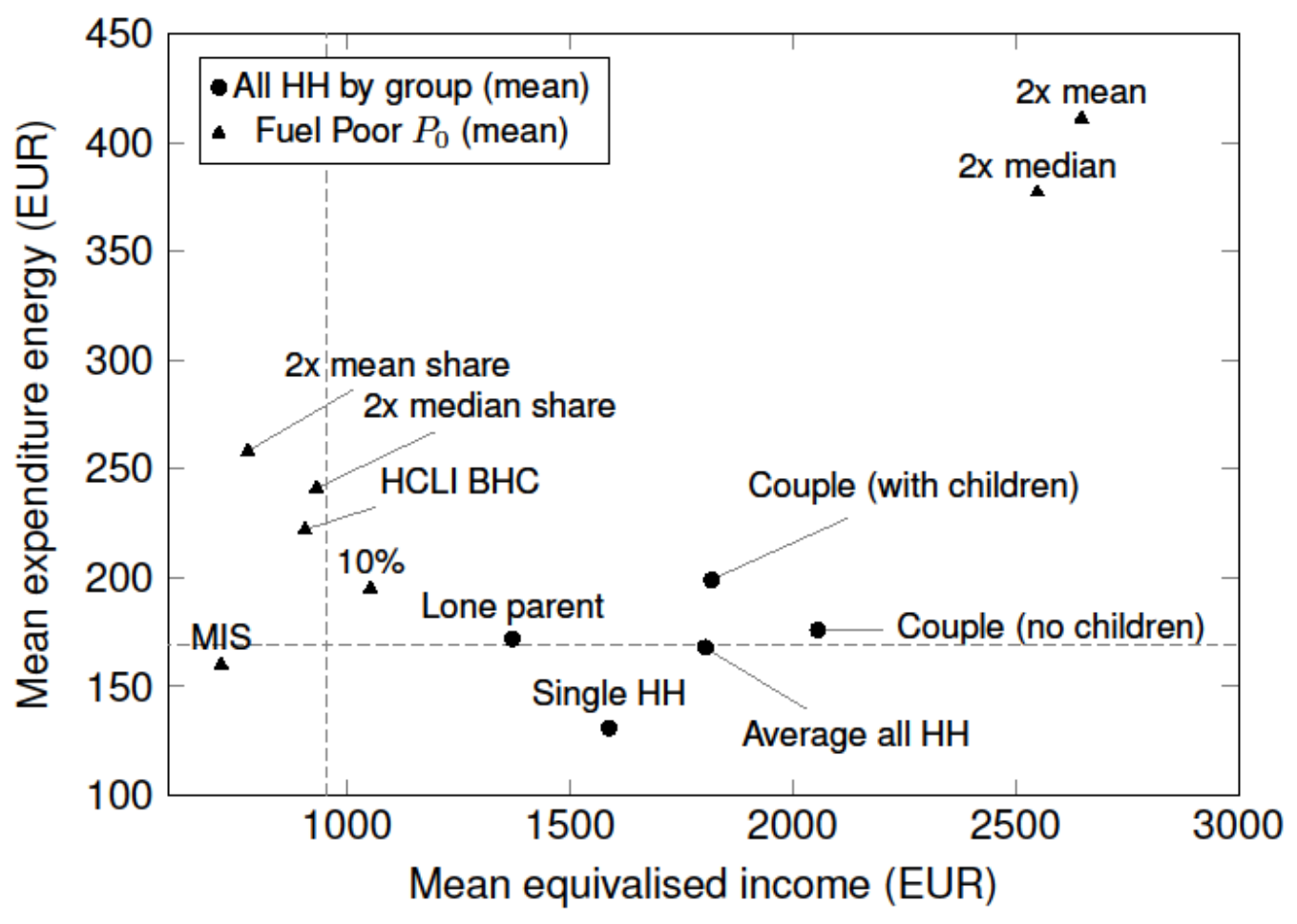

Figure 2: Mean of equivalised income and all expenditures on energy services in EUR for all households in the sample and several subgroups and within the groups of "fuel poor" evaluated based on different fuel poverty lines. 
Table 3: Fuel poverty measures for Germany (2011)

\begin{tabular}{|c|c|c|c|c|c|}
\hline Type & $\begin{array}{lr}\text { Share } & \text { fuel } \\
\text { poor } & \text { in } \\
\text { sample } & \end{array}$ & $\begin{array}{l}\text { Share of } \\
\text { fuel poor } \\
\text { (population } \\
\text { weights) }\end{array}$ & $\begin{array}{l}\text { Average } \\
\text { equivalised } \\
\text { Income of fuel } \\
\text { poor (BHC) }\end{array}$ & $\begin{array}{l}\text { Share of fuel } \\
\text { poor below } \\
\text { poverty line } \\
\text { (952 EUR) }\end{array}$ & $\begin{array}{l}\text { Average exp. } \\
\text { on energy } \\
\text { services of } \\
\text { fuel poor } \\
\text { (equiv. } \\
\text { income) }\end{array}$ \\
\hline $\begin{array}{l}10 \% \mathrm{NE} \\
\mathrm{BHC}\end{array}$ & $25.1 \%$ & $29.8 \%$ & 1,054 & $45.7 \%$ & $20.3 \%$ \\
\hline $\begin{array}{l}\text { 2x median } \\
\text { expenditure }\end{array}$ & $4.6 \%$ & $4.1 \%$ & 2,549 & $8.1 \%$ & $21.5 \%$ \\
\hline $\begin{array}{l}\text { 2x median } \\
\text { share of exp. }\end{array}$ & $11.2 \%$ & $12.0 \%$ & 933 & $58.2 \%$ & $28.2 \%$ \\
\hline $\begin{array}{l}\text { 2x mean } \\
\text { expenditure }\end{array}$ & $2.9 \%$ & $2.4 \%$ & 2,648 & $7.9 \%$ & $22.1 \%$ \\
\hline $\begin{array}{l}2 x \text { mean } \\
\text { share of exp. }\end{array}$ & $4.9 \%$ & $5.4 \%$ & 779 & $74.8 \%$ & $36.5 \%$ \\
\hline MIS (SGBII) & $8.8 \%$ & $9.9 \%$ & 721 & $89.2 \%$ & $25.0 \%$ \\
\hline $\begin{array}{l}\text { HCLI EI } \\
\text { BHC }\end{array}$ & $10.5 \%$ & $11.1 \%$ & 907 & $52.2 \%$ & $26.3 \%$ \\
\hline $\begin{array}{l}\text { HCLI EI } \\
\text { AHC }\end{array}$ & $12.6 \%$ & $13.7 \%$ & 998 & $43.5 \%$ & $24.5 \%$ \\
\hline
\end{tabular}

When the share of fuel poor is broken down to several subgroups for different fuel poverty lines, some conceptual differences of the fuel poverty lines are revealed (Table 4). The 10 per cent measure identifies single households as the most vulnerable type of households. This is in strong contrast to all other concepts. This is because the 10 per cent approach is based on non-equivalised income and neglects scale effects. The two times median and two times mean expenditure concepts identify other $\mathrm{HH}$ as most vulnerable household types, while the figures for lone parents are relatively low and similar to those for couples without children. The two times median share and two times mean share poverty lines both identify lone parents as the most vulnerable household type. Also the MIS and HCLI identify lone parents and other households as most vulnerable. 
Interestingly, MIS and HCLI differ strongly with regard to the figures for single HH and couples with children. While the MIS ranks single $\mathrm{HH}$ as the third most impacted group and figures for couples with children are relatively low, the HCLI (and the two times median share) ranks couples with children as a household type that is more frequently subject to fuel poverty compared to single HH or couples without children. This likely goes back on the definition of the MIS that is based on SGB II rates, which include additional allocation for children. This limits the applicability of SGB II rates as MIS for families that do not receive public assistance, i.e. in cases where equivalised household income is low for some reason.

Table 4: Share of fuel poor for different measures in subgroups (results with population share weights in parenthesis) in per cent

\begin{tabular}{l|l|l|l|l|l} 
& Single HH & $\begin{array}{l}\text { Couple no } \\
\text { Children } \\
\mathrm{n}=3722\end{array}$ & $\begin{array}{l}\text { Lone parent } \\
\mathrm{n}=3064\end{array}$ & $\begin{array}{l}\text { Couple with } \\
\text { Children } \\
\mathrm{n}=2553\end{array}$ & $\mathrm{n}=152$ \\
\hline $\begin{array}{l}10 \% \mathrm{NE} \\
\text { BHC }\end{array}$ & $41.3 \%(42.7)$ & $18.1 \%(20.3)$ & $38.5 \%(39.8)$ & $12.1 \%(14.6)$ & $25.7 \%(28.2)$ \\
2x median & $1.6 \%(1.6)$ & $4.6 \%(5.0)$ & $5.4 \%(4.5)$ & $7.9 \%(7.8)$ & $7.9 \%(7.4)$ \\
$\begin{array}{l}\text { 2x median } \\
\text { share of exp. }\end{array}$ & $8.3 \%(8.9)$ & $8.3 \%(9.5)$ & $20.5 \%(22.4)$ & $16.0 \%(18.5)$ & $17.8 \%(20.3)$ \\
$\begin{array}{l}\text { 2x mean } \\
\text { 2x mean } \\
\text { share of exp. }\end{array}$ & $0.8 \%(0.8)$ & $2.7 \%(2.9)$ & $3.8 \%(3.2)$ & $4.9 \%(4.4)$ & $7.9 \%(7.4)$ \\
MIS & $12.6 \%(12.3)$ & $4.7 \%(5.5)$ & $18.4 \%(20.6)$ & $7.1 \%(8.1)$ & $16.4 \%(17.0)$ \\
$\begin{array}{l}\text { HCLI EI } \\
\text { BHC }\end{array}$ & $7.4 \%(7.8)$ & $8.1 \%(9.0)$ & $20.7 \%(24.4)$ & $14.6 \%(16.6)$ & $16.4 \%(17.2)$ \\
$\begin{array}{l}\text { HCLI EI } \\
\text { AHC }\end{array}$ & $9.6 \%(10.7)$ & $8.8 \%(9.8)$ & $25.2 \%(29.4)$ & $17.8 \%(20.3)$ & $19.1 \%(19.8)$ \\
\end{tabular}

Comparing the correlation of the different fuel poverty lines gives an indication about the proximity of the different fuel poverty lines (Table 5). The 10 per cent measure shows relatively high correlation to MIS, HCLI, and two times median/mean share but is not a perfect substitute. The two 
times median and two times mean expenditure concepts show weak correlation to the remaining fuel poverty measures. The HCLI concept has a relatively high correlation to the 10 per cent measure, high correlation to the BHC and AHC concept, and median or mean share measure as well. For the MIS measure, correlation to most of the remaining measures, i.e. to the HCLI, is less pronounced than expected.

Table 5: Pairwise correlation of fuel poverty measures (Germany 2011, results with population share weights in parenthesis)

\begin{tabular}{|c|c|c|c|c|c|c|c|c|}
\hline & ᄋ̊ㅁㅁ & 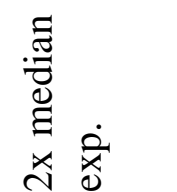 & 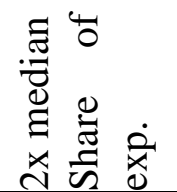 & 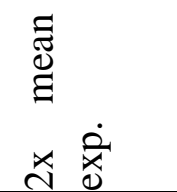 & 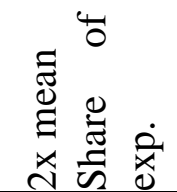 & $\stackrel{\mathscr{N}}{\Sigma}$ & 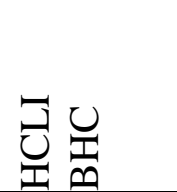 & 录茎 \\
\hline $10 \%$ & 1.0000 & & & & & & & \\
\hline $\begin{array}{l}2 \mathrm{x} \\
\text { median } \\
\text { expenditu } \\
\text { re }\end{array}$ & $\begin{array}{l}0.1263 * * \\
* \\
(0.1132)\end{array}$ & 1.0000 & & & & & & \\
\hline $\begin{array}{l}2 \mathrm{x} \\
\text { median } \\
\text { share of } \\
\text { exp. }\end{array}$ & $\begin{array}{l}0.5322 * * \\
* \\
(0.5033)\end{array}$ & $\begin{array}{l}0.2344 * * \\
* \\
(0.2337)\end{array}$ & 1.0000 & & & & & \\
\hline $\begin{array}{l}\text { 2x mean } \\
\text { expenditu } \\
\text { re }\end{array}$ & $\begin{array}{l}0.1032 * * \\
* \\
(0.0999)\end{array}$ & $\begin{array}{l}0.7797 * * \\
* \\
(0.7539)\end{array}$ & $\begin{array}{l}0.2058 * * \\
* \\
(0.2134) \\
\end{array}$ & 1.0000 & & & & \\
\hline $\begin{array}{l}\text { 2x mean } \\
\text { share of } \\
\text { exp. }\end{array}$ & $\begin{array}{l}0.3863 * * \\
* \\
(0.3599)\end{array}$ & $\begin{array}{l}0.2134 * * \\
* \\
(0.2170)\end{array}$ & $\begin{array}{l}0.6405 * * \\
* \\
(0.6465)\end{array}$ & $\begin{array}{l}0.1949 * * \\
* \\
(0.2095)\end{array}$ & 1.0000 & & & \\
\hline MIS & $\begin{array}{l}0.4293 * * \\
* \\
(0.4348)\end{array}$ & $\begin{array}{l}-0.0005 \\
(0.0013)\end{array}$ & $\begin{array}{l}0.4437 * * \\
* \\
(0.4639)\end{array}$ & $\begin{array}{l}0.0030 \\
(0.0026)\end{array}$ & $\begin{array}{l}0.4332 * * \\
* \\
(0.4304)\end{array}$ & 1.0000 & & \\
\hline $\begin{array}{l}\text { HCLI } \\
\text { BHC }\end{array}$ & $\begin{array}{l}0.4772 * * \\
* \\
(0.4464)\end{array}$ & $\begin{array}{l}0.0649 * * \\
* \\
(0.0706)\end{array}$ & $\begin{array}{l}0.6569 * * \\
* \\
(0.6570)\end{array}$ & $\begin{array}{l}0.0526 * * \\
* \\
(0.0617)\end{array}$ & $\begin{array}{l}0.5302 * * \\
* \\
(0.5270)\end{array}$ & $\begin{array}{l}0.3137 * * \\
* \\
(0.3196)\end{array}$ & 1.0000 & \\
\hline $\begin{array}{l}\text { HCLI } \\
\text { AHC }\end{array}$ & $\begin{array}{l}0.4677 * * \\
* \\
(0.4525)\end{array}$ & $\begin{array}{l}0.0871 * * \\
* \\
(0.1016)\end{array}$ & $\begin{array}{l}0.6112 * * \\
* \\
(0.6026)\end{array}$ & $\begin{array}{l}0.0610 * * \\
* \\
(0.0832)\end{array}$ & $\begin{array}{l}0.4800 * * \\
* \\
(0.4752)\end{array}$ & $\begin{array}{l}0.2956 * * \\
* \\
(0.2899)\end{array}$ & $\begin{array}{l}0.8096 * * \\
* \\
(0.8022)\end{array}$ & $\begin{array}{l}1.000 \\
0\end{array}$ \\
\hline
\end{tabular}

*** Significance level $<0.01 \%$ 
Poverty lines can be compared so that they would yield similar shares of households potentially subject to fuel poverty ${ }^{18}$. Since poverty lines as the 10 per cent or two times median expenditure approach are chosen arbitrarily, the comparison can also strengthen the intuition about what would be comparable shares of expenditure on energy services relative to fuel poverty lines that (partially) rely on income poverty lines, such as the HCLI. Table 6 compares the $\mathrm{X}$ per cent expenditure and median expenditure concept to the HCLI BHC fuel poverty line. A 10 per cent expenditure share fuel poverty line, as previously applied in the UK, seems to be too restrictive for the case of Germany. A similar share of fuel poor as in the HCLI BHC would be obtained at a level of 14 per cent expenditure on all energy services relative to non-equivalised income. The 10 per cent poverty line would be equivalent to an income poverty line of EUR 1,480 in the HCLI BHC concept. This is far above the official poverty line of EUR 954. Also a fuel poverty line of 1.65 times median expenditures on all energy services would yield a similar share of fuel poor when compared to the HCLI BHC. The two times median expenditure approach would be equivalent to a EUR 690 income poverty line in the HCLI BHC approach, which is far below the official poverty line.

Table 6: In-sample sensitivity of fuel poverty lines (Germany 2011)

\begin{tabular}{|c|c|c|c|}
\hline & $10 \%$ & $\begin{array}{l}2 \mathrm{x} \\
\text { expenditure }\end{array}$ & HCLI BHC \\
\hline $10 \%$ non-equiv. $\mathrm{BHC}$ & $10 \%$ & $18.5 \%$ & $14 \%$ \\
\hline $\begin{array}{ll}2 \mathrm{x} & \text { median } \\
\text { expenditure } & \end{array}$ & 1.3 x Median & 2 x Median & 1.65 x Median \\
\hline HCLI BHC & $\begin{array}{l}\text { 1,480 EUR poverty } \\
\text { line }\end{array}$ & $\begin{array}{l}690 \text { EUR poverty } \\
\text { line }\end{array}$ & $\begin{array}{l}954 \text { EUR poverty } \\
\text { line }\end{array}$ \\
\hline
\end{tabular}

The comparison of fuel poverty lines for the case of Germany has shown that the different concepts identify a different number and different types of households as fuel poor (Table 3 to 5). The two times median expenditure and two times mean expenditure concepts fail to identify poor households (in terms of income) and capture some households with relatively high income that face high expenditures on all energy services for some reasons. The 10 per cent approach is chosen

\footnotetext{
${ }^{18}$ This does not imply that the same households are identified as fuel poor.
} 
arbitrarily, but could be modified so that it yields a similar share of fuel poor as the HCLI BHC approach when setting the fuel poverty line equal to 14 per cent of expenditure. However, the 14 per cent and HCLI would not identify the same households as fuel poor. The correlation between both approaches is about 50 per cent with a larger variance of incomes for the 14 per cent threshold compared to HCLI BHC, where the 14 per cent approach captures some wealthier households than the HCLI BHC. The MIS fuel poverty line that is based on German social benefit rates (SGB II) yields lower figures of fuel poverty than the HCLI, the 10 per cent, and median/mean share measures because of a relatively low poverty line implied by SGB II rates. Single HH are identified as the most vulnerable types of households when using MIS SGB II, which is in strong contrast to the other fuel poverty lines. Thus, SGB II rates seem to be inappropriate as MIS in this case because of the design of SGB II rate allocation for different types of households. However, the use of MIS SGB II shows that there is indeed a risk that increasing expenditures on energy services might lead to a decrease in labour supply of poor households, i.e. since costs for space heating are fully born by the welfare agency. The HCLI poverty line is able to identify poorer households as fuel poor by definition and rules out cases in which high expenditure on energy services is driven by high income and specific preferences. Surprisingly, the two times median expenditure share measure yields results which are similar to the HCLI approach with relatively high correlation of households identified as fuel poor.

\subsection{Analysing Fuel Poverty: An Example}

The FGT class poverty measure allows for subgroup comparison of $j=1 \ldots m$ groups with income vector $y$ broken down to $y^{(1)}, \ldots, y^{(m)}$ income vectors and subgroup population share weights $n_{j} / n$. A subgroup's contribution to total poverty is $\left(n_{j} / n\right) P_{\alpha}\left(y^{(j)} ; z\right)$ and the percentage contribution of a subgroup to overall poverty is given by $100\left(n_{j} / n\right)\left(P_{\alpha}\left(y^{(j)} ; z\right) / P_{\alpha}(y ; z)\right.$ ) (Foster, Greer and Thorbecke, 1984, pp. 763-764). Based on this, a detailed comparison of subgroups and their 
contribution to overall fuel poverty is possible, once a certain poverty line has been agreed on. The example below assumes the HCLI BHC poverty line. In addition to the share of households subject to fuel poverty $\left(P_{0}\right)$, the squared poverty gap index $\left(P_{2}\right)$ is calculated to capture the depth of poverty within the groups. Each group's contribution to $P_{2}$ in absolute figures and per cent is calculated to compare the relative importance of a group for overall fuel poverty. This can deliver valuable information for "targeting" of policies for fuel poverty reduction. The measure $P_{\alpha}$ is comparable between subgroups, which allows an assessment of which group is the most vulnerable according to a certain $P_{\alpha}$.

The results from subgroup comparison based on the HCLI BHC and the $P_{2}$ FGT measure are reported in Table 7 . According to $P_{2}$, the groups of lone parents, other $\mathrm{HH}$, and couples with children are households where fuel poverty is "deepest"19. Because of the size of the groups of single $\mathrm{HH}$ and couples without children, their contribution to overall poverty is about $50 \%$, although fuel poverty is not as “deep” as among the remaining groups. The contribution of the group of other $\mathrm{HH}$ and lone parents to overall poverty is relatively small with 2.3 per cent and 13.8 per cent respectively, while fuel poverty is relatively severe in these groups. If the government aims to reduce the share of overall "fuel poor" based on the $P_{0}$, it could be tempted to introduce policies that target the groups of households where fuel poverty is not very deep but which jointly contribute to a large amount to $P_{0}$, such as single $\mathrm{HH}$ or couples without children. If the objective is to reduce fuel poverty amongst those households which are most severely concerned, the targeting schedule would prefer lone parents and other households, followed by couples with children. Table 8 shows ranked targeting schedules based on different indicators of poverty. Depending on which indicators are chosen to set up (targeted) policies for poverty reduction, the targeting schedule will look different. As the example has shown, policies that aim to minimise $P_{0}$ might fail to identify the most

\footnotetext{
${ }^{19}$ For lone parents in Germany it was shown that their poverty risk is about two times higher when compared to other household types (IAB, 2009).
} 
vulnerable households or those that are most concerned with fuel poverty. Therefore, the use of poverty measures with $\alpha>1$ and disaggregation of the overall population in subgroups is recommended in order to identify households that are most vulnerable to changes in energy prices or fuel poverty in general and to assess the impact of policies that aim to reduce fuel poverty over time.

Table 7: In-sample subgroup comparison based on the HCLI BHC measure

\begin{tabular}{l|l|l|l|l|l|l} 
HH Group & $\mathrm{n}$ & $\begin{array}{l}\text { fuel poor } \\
\text { (per cent) }\end{array}$ & $\mathrm{P} 2$ & $\begin{array}{l}\text { Contribution } \\
\text { to overall P2 }\end{array}$ & $\begin{array}{l}\text { Contribution } \\
\text { P2 (per } \\
\text { cent) }\end{array}$ & $\begin{array}{l}\text { Eq- } \\
\text { Income } \\
\text { (Mean) }\end{array}$ \\
\hline All HH & 10,193 & $10.5 \%$ & 0.0130055 & - & - & 1,805 \\
\hline Single HH & 3,064 & $7.4 \%$ & 0.0100215 & 0.0030124 & $23.2 \%$ & 1,589 \\
$\begin{array}{l}\text { Couple } \\
\text { (no } \\
\text { children) }\end{array}$ & 3,722 & $8.1 \%$ & 0.009164 & 0.0033463 & $25.7 \%$ & 2,057 \\
$\begin{array}{l}\text { Lone } \\
\text { Parent }\end{array}$ & 702 & $20.7 \%$ & 0.0259932 & 0.0017902 & $13.8 \%$ & 1,372 \\
$\begin{array}{l}\text { Couple } \\
\text { (w. } \\
\text { children) }\end{array}$ & 2,553 & $14.6 \%$ & 0.0182137 & 0.0045619 & $35.1 \%$ & 1,819 \\
$\begin{array}{l}\text { Other HH } \\
\text { Total }\end{array}$ & 152 & $16.5 \%$ & 0.019764 & 0.0002947 & $2.3 \%$ & 1,760 \\
\hline
\end{tabular}

Table 8: Targeting schedule based on different fuel poverty indicators from the HCLI BHC measure

\begin{tabular}{|c|c|c|c|c|}
\hline Rank & P0 & $\mathbf{P} 2$ & $\begin{array}{l}\text { Contribution to } \\
\text { P2 }\end{array}$ & Eq-Income \\
\hline 1 & Lone Parents & Lone Parents & $\begin{array}{l}\text { Couple } \\
\text { Children }\end{array}$ & Lone Parents \\
\hline 2 & Other HH & Other HH & $\begin{array}{ll}\text { Couple } & \text { no } \\
\text { Children } & \end{array}$ & Single HH \\
\hline 3 & $\begin{array}{l}\text { Couple } \quad+ \\
\text { Children }\end{array}$ & $\begin{array}{l}\text { Couple } \\
\text { Children }\end{array}$ & Single HH & Other HH \\
\hline 4 & $\begin{array}{ll}\text { Couple } & \text { no } \\
\text { Children } & \end{array}$ & Single HH & Lone Parents & $\begin{array}{l}\text { Couple } \\
\text { Children }\end{array}$ \\
\hline 5 & Single HH & $\begin{array}{ll}\text { Couple } & \text { no } \\
\text { Children } & \end{array}$ & Other HH & $\begin{array}{l}\text { Couple } \\
\text { Children }\end{array}$ \\
\hline
\end{tabular}




\section{Concluding Remarks}

In this paper, options for fuel poverty measurement and the definition of a fuel poverty line were discussed. The application of different fuel poverty lines on German microdata from the socioeconomic panel has shown that the poverty lines partly differ strongly with respect to which households are identified as fuel poor. This shows that the choice of fuel poverty line matters decisively for the resulting fuel poverty assessment. Overall, it appears that an $X$ per cent poverty line is a rough measure of fuel poverty and fails to fully identify households which are less wealthy. As noted by Moore (2012), figures resulting from this fuel poverty line are highly sensitive to temporary changes in fuel prices, which is a clear disadvantage. Poverty lines, such as the $X$ times median expenditure or $X$ times mean expenditure approach, fully fail to identify poorer households. In contrast, the $X$ times median/mean expenditure share measure identifies households with relatively low income and high fuel costs. Concepts like the "high cost/low income" (HCLI) poverty line, originally proposed by Hills (2012), or a "minimum income standard” offer high accuracy in identifying poorer households with high expenditure on energy services. They also show relatively strong correlation to the two times median expenditure share concept. While the HCLI can be applied to German data without any limitation, the MIS based on SGB II benefit rates seems to be less appropriate, i.e. because a poverty line below the official poverty line of 60 per cent median income would be implied by the SGB II rates. A strong feature of the HCLI is that the poverty line is directly related to the income poverty line of 60 per cent median income, which allows for some comparison with figures in income poverty and contributes to a better understanding of complex fuel poverty patterns and related issues of justice (Walker and Day, 2012). Interestingly, fuel poverty augments income poverty assessments, i.e. in the case of the HCLI, since about half of households identified as fuel poor by the HCLI are not identified as income-poor based on the income poverty line, but fall below the income poverty line after expenses on energy services. Overall, the two times median share poverty line and the HCLI 
poverty line, which show strong correlation, seem to be the most appropriate fuel poverty lines compared to the remaining options considered in this paper. In order to account for household composition, using equivalised income is clearly to be preferred over non-equivalised income.

Once a fuel poverty line has been chosen, fuel poverty measurement can take place based on existing advanced techniques of poverty measurement, such as the class of poverty measure proposed by Foster, Greer and Thorbecke (1984). The FGT class poverty measures allow for subgroup comparison, which is an important tool in order to identify the most vulnerable groups of households. The potential of the FGT class poverty measure goes far beyond the application presented in this paper and could be expanded to cover a regional comparison as well. Although poverty measurement is often based on the headcount ratio $\left(P_{0}\right)$, as for example in the German income poverty assessment (BMAS, 2013), it is strongly recommended to go beyond the headcount ratio for fuel poverty measurement, e.g. by using the squared poverty gap index $\left(P_{2}\right)$, to account for the transfer axiom (Foster et al., 1984; Sen, 1976). The application of the squared poverty gap index would further help to identify potentially unwanted regressive effects of policies that aim to reduce fuel poverty over time. As a research perspective, the application of multidimensional poverty measures (Alkire and Foster, 2011) to the case of fuel poverty in developed countries, potentially jointly with aspects of income poverty, could be considered.

For the case of Germany, the socio-economic panel offers a rich dataset on households that includes a large number of socio-economic variables beyond income and energy expenditure. A second option, however, would be to assess fuel poverty based on household data from the German statistical office (Laufende Wirtschaftsrechnung and/or Einkommens- und Verbrauchsstichprobe), which likely offers even more accurate data on actual household expenditure on energy services and other categories. Since the aim of this paper was not to generate some particular figures on energy poverty in Germany, but to discuss and compare different fuel poverty lines and options for fuel poverty measurement, this issue is left to further research. 


\section{References:}

Abrahamse, W., Steg, L. (2009), How do socio-demographic and psychological factors relate to households' direct and indirect energy use and savings?, J. Econ. Psychol. 30, 711-720.

Achtnicht, M., Madlener, R. (2012), Factors Influencing German House Owners’ Preferences on Energy Retrofits, ZEW Discuss. Pap. 12-042.

Alkire, S., Foster, J. (2011), Counting and multidimensional poverty measurement, J. Public Econ. 95, 476-487.

Allcott, H., Mullainathan, S. (2010), Behavioral science and energy policy, Science (80-. ). 327, 1204-1205.

Atkinson, A.B. (1987), On the Measurement of Poverty, Econometrica 55, 749-764.

Banerjee, A. V, Duflo, E. (2007), The Economic Lives of the Poor, J. Econ. Perspect. 21, 141-167.

BMAS (2013), Lebenslagen in Deutschland, Bundesministerium für Arbeit und Soziales, Berlin.

BMWi (2012), First Monitoring Report “Energy of the future”, Berlin.

Boardman, B. (1991), Fuel Poverty: From Cold Homes to Affordable Warmth, Belhaven Press, London.

Bradshaw, J., Middleton, S., Davis, A., Oldfield, N., Smith, N., Cusworth, L., Williams, J. (2008), A Minimum Income Standard for Britain, Leicestershire, UK.

Brounen, D., Kok, N., Quigley, J.M. (2012), Residential energy use and conservation: Economics and demographics, Eur. Econ. Rev. 56, 931-945.

CEER (2012), CEER Status Review of Customer and Retail Market Provisions from the 3rd Package as of 1 January 2012, Brussels.

Coudouel, A., Hentschel, J.S., Wodon, Q.T. (2002), Poverty Measurement and Analysis, in: Jeni Klugman (Ed.), A Sourcebook for Poverty Reduction Strategies - Volume 1: Core Techniques and Cross-Cutting Issues. The World Bank, Washington D.C., pp. 27-74.

Department of Energy and Climate Change (2013), Annual Report on Fuel Poverty: Statistics 2013, London, UK.

E-Control (2013), Energiearmut in Österreich - Definitionen und Indikatoren, Energie-Control Austria, Wien.

EU (2009a), Directive 2009/72/EC of the European Parliament and of the Council of 13 July 2009 concerning common rules for the internal market in electricity and repealing Directive 2003/54/EC, Brussels. 
EU (2009b), Directive 2009/73/EC of the European Parliament and the Council of 13 July 2009 concerning common rules for the internal market in natural gas and repealing Directive 2003/55/EC, Brussels.

European Commission (2010), An Energy Policy for Consumers, Eur. Comm. Staff Work. Pap. No. 1407.

Foster, J., Greer, J., Thorbecke, E. (1984), A Class of Decomposable Poverty Measures, Econometrica 52, 761-766.

Goldhammer, K., Mans, U., Rivera, M. (2013), Beiträge zur sozialen Bilanzierung der Energiewende, Potsdam.

Hagenaars, A., de Vos, K., Zaidi, M.A. (1994), Poverty Statistics in the Late 1980s: Research Based on Micro-data, Office for Official Publications of the European Communities, Luxembourg.

Healy, J.D., Clinch, J.P. (2004), Quantifying the severity of fuel poverty, its relationship with poor housing and reasons for non-investment in energy-saving measures in Ireland, Energy Policy 32, 207-220.

Hills, J. (2012), Getting the Measure of Fuel Poverty: Final Report of the Fuel Poverty Review, London.

IAB (2009), Bedarfsgemeinschaften im SGB II: Warum Alleinerziehende es besonders schwer haben, IAB-Kurzbericht, Inst. für Arbeitsmarkt und Berufsforschung, Nürnb. 12-2009.

IEA (2013), Energy Policies of IEA Countries: Germany 2013 Review, International Energy Agency, Paris.

Kakwani, N. (1980), On a Class of Poverty Measures, Econometrica 48, 437-446.

Kriström, B. (2008), Residential Energy Demand, in: Household Behaviour and the Environment: Reviewing the Evidence. OECD Publishing, Paris, pp. 97-115.

Kriström, B. (2013), Residential Energy Demand, Encycl. Energy, Nat. Resour. Environ. Econ. 1, 218-224.

Liddell, C., Morris, C., McKenzie, S.J.P., Rae, G. (2012), Measuring and monitoring fuel poverty in the UK: National and regional perspectives, Energy Policy 49, 27-32.

Meier, H., Rehdanz, K. (2010), Determinants of residential space heating expenditures in Great Britain, Energy Econ. 32, 949-959.

Moore, R. (2012), Definitions of fuel poverty: Implications for policy, Energy Policy 49, 19-26.

Nesbakken, R. (1999), Price sensitivity of residential energy consumption in Norway, Energy Econ. 21, 493-515.

Neuhoff, K., Bach, S., Diekmann, J., Beznoska, M., El-Laboudy, T. (2012), Steigende EEGUmlage: Unerwünschte Verteilungseffekte können vermindert werden, DIW Wochenbericht $413-12$. 
Neuhoff, K., Bach, S., Diekmann, J., Beznoska, M., El-Laboudy, T. (2013), Distributional Effects of Energy Transition: Impacts of Renewable Electricity Support in Germany, Econ. Energy Environ. Policy 2.

Nguyen-Van, P. (2010), Energy consumption and income: A semiparametric panel data analysis, Energy Econ. 32, 557-563.

OECD (2011), Divided We Stand: When Inequality Keeps Rising, OECD Publishing, Paris.

Ravallion, M., Chen, S., Sangraula, P. (2009), Dollar a Day Revisited, World Bank Econ. Rev. 23, 163-184.

Ravallion, M., Datt, G., van de Walle, D. (1991), Quantifying Absolute Poverty in the Developing World, Rev. Income Wealth 37, 345-361.

Rehdanz, K. (2007), Determinants of residential space heating expenditures in Germany, Energy Econ. 29, 167-182.

Reiss, P.C., White, M.W. (2005), Household Electricity Demand, Revisited, Rev. Econ. Stud. 72, 853-883.

Reiss, P.C., White, M.W. (2008), What changes energy consumption? Prices and public pressures, RAND J. Econ. 39, 636-663.

Sen, A. (1976), Poverty: An Ordinal Approach to Measurement, Econometrica 44, 219-231.

Ürge-Vorsatz, D., Tirado Herrero, S. (2012), Building synergies between climate change mitigation and energy poverty alleviation, Energy Policy 49, 83-90.

Wagner, G.G., Frick, Joachim, R., Schupp, J. (2007), The German Socio-Economic Panel Study (SOEP) - Scope, Evolution and Enhancements, Schmollers Jahrb. 127, 139-169.

Walker, G., Day, R. (2012), Fuel poverty as injustice: Integrating distribution, recognition and procedure in the struggle for affordable warmth, Energy Policy 49, 69-75.

Watts, H. (1968), An economic definition of poverty, in: Moynihan, D.P. (Ed.), On Understanding Poverty. Basic Books, New York.

Zheng, B. (1997), Aggregate Poverty Measures, J. Econ. Surv. 11, 123-162. 


\section{Appendix 1: SGB II rates for MIS}

The MIS was calculated on the household level for each individual household according to household composition and size. SGB II rates taken for MIS calculation were EUR 382 per month for the first adult person in the household, EUR 345 for the second adult person, EUR 289 for a dependent child older than 16 years, and EUR 255 for a dependent child of age 16 or younger. Costs for electricity were subtracted from the SGBII rates to capture the non-energy related component of the SGBII rate based MIS. Subtraction is based on average costs for electricity of all households. A household is regarded as subject to fuel poverty if

$$
P_{0, M I S}=\left\{\begin{array}{l}
1 \text { if inc } c_{\text {ahe }}-c_{\text {energ }}-\text { MIS } \leq 0 \\
0 \text { if inc } c_{\text {ahe }}-c_{\text {energ }}-\text { MIS }>0
\end{array} .\right.
$$

SGB II rates and equivalised disposable income (using the new OECD scale) are different concepts. The SGB II implicitly gives lower weighs to the first and second adult person in the HH but higher weights to children when compared to the new OECD equivalence scale. A couple with one child younger than 16 years would receive about 982 EUR under SGB II. The allocation is 382 EUR (39\%) for the first adult, 345 EUR (35\%) for the second adult, and 255 EUR (26\%) for the child. If an income of 982 EUR would be distributed to the family members based on the new OECD equivalence scale, the allocation would be 546 EUR (56\%) for the first adult, 273 EUR (28\%) for the second adult, and 163 EUR (17\%) for the child. Thus, there are considerable differences in the implicit scale of SGB II rates when compared to the new OECD equivalence scale. 
Appendix 2: Summary statistics

Table 9: Summary statistics SOEP sample 2011, n=10,201, currency EUR 2010

\begin{tabular}{l|l|l|l|l|l} 
Variable & Mean & Median & SD & Min. & Max. \\
\hline HH Income & 2762.99 & 2300,00 & 2020.98 & 70 & 55000 \\
Equivalised HH income & 1805.04 & 1555,56 & 1181.85 & 70 & 36666.67 \\
Costs electricity & 66.21 & 62.58 & 32.61 & 0 & 950 \\
Costs heating & 101.99 & 90.00 & 57.41 & 0 & 833.25 \\
Overall energy costs & 168.21 & 155.00 & 74.92 & 0 & 1100 \\
Number of persons in HH & 2.15 & 2 & 1.07 & 1 & 6 \\
Dummy single HH & 0.301 & - & 0.4585 & 0 & 1 \\
Dummy couple no children & 0.365 & - & 0.4814 & 0 & 1 \\
Dummy lone parent & 0.069 & - & 0.2532 & 0 & 1 \\
Dummy couple with & 0.250 & - & 0.4333 & 0 & 1 \\
children & & & & &
\end{tabular}




\section{Appendix 3:}

Section 4.1 described the procedure of imputation for missing data on the costs for electricity which were unavailable for 2,560 households that own property. We predict the costs for electricity by running an ordinary least square (OLS) regression with the cost of electricity as dependent variable and a larger set of independent variables (see Table 10). Independent variables include the living space in square meters (wohnfl), the number of rooms (zimmer), dummies for the period in which a house was built (Dbaujahr), dummies for household composition (DHHdet), the state in which the house is located (Dbland), and disposable income (eink_bhc) in Euro.

The dummy categories for Dbaujahr are: 1=before $1918,2=1918$ to 1948 , 3=1949 to 1971, 4=1972 to $1980,5=1981$ to $1990,6=1991$ to $2000,7=2001$ or later (reference category).

The dummy categories for DHHdet are: $1=$ single male at age 35 or younger, $2=$ single male $35-60$ years, $3=$ single male 60 years or older, $4=$ single female at age 35 or younger, $5=$ single female 35-60 years, single female at age 60 or older, $7=$ couple no children, $8=$ =lone parent with one child at age 16 or younger, $9=$ =lone parent two children at age 16 or younger, $10=$ lone parent one child at age 16 or older, $11=$ =lone parent two or more children at age 16 or older, $12=$ lone parent two children at age 16 and one child at age 16 or older. $13=$ lone parent three or more children, $14=$ couple one child at age 16 or younger, $15=$ couple two children at age $16,16=$ couple three or more children at age 16 or younger, $17=$ couple one child at age 16 or older, $18=$ couple two children at age 16 or older, 19=couple three children at age 16 or younger, $20=$ couple two children at age 16 one child at age 16 or older, $21=$ couple three children or more at age 16 or younger and at age 16 or older. The remaining categories are "other type of households” and represent the reference category.

The dummy categories for bland (German states) are: 
1=Baden-Württemberg, 2=Bavaria (Freistaat Bayern), 3=Berlin, 4=Brandenburg, 5=Bremen, 6=Hamburg, 7=Hesse (Hessen), 8=Mecklenburg-Vorpommern, 9=Lower Saxony (Niedersachsen), 10=North Rhine Westphalia (Nordrhein-Westfalen), 11=Rhineland Palatinate (Rheinland-Pfalz), 12=Saarland,13= Saxony (Sachsen), 14=Saxony-Anhalt (Sachsen-Anhalt), 15=Schleswig-Holstein, 16=Thuringia (Thüringen). Reference category is Dbland1 (Baden-Württemberg).

The regression results are shown in Table 10. Missing values on electricity expenditure of 2,560 households that own property are generated by fitting the model to the respective observation (prediction).

Table 10: Regression results for imputation of electricity costs for households which own property. Dependent variable k_strom (costs for electricity).

\begin{tabular}{lc}
\hline & \\
VARIABLES & k_strom \\
\hline \multirow{2}{*}{ wohnfl } & $0.197 * * *$ \\
& $(0.0273)$ \\
zimmer & 0.248 \\
& $(0.708)$ \\
Dbaujahr1 & $15.99^{* * *}$ \\
& $(3.720)$ \\
Dbaujahr2 & $17.15^{* * *}$ \\
& $(3.746)$ \\
Dbaujahr3 & $15.18^{* * *}$ \\
& $(3.439)$ \\
Dbaujahr4 & $17.41^{* * *}$ \\
& $(3.634)$ \\
Dbaujahr5 & $15.25^{* * *}$ \\
& $(3.787)$ \\
Dbaujahr6 & $8.570^{* *}$ \\
& $(3.614)$ \\
DHHdet1 & $-33.47^{* *}$ \\
& $(13.20)$ \\
DHHdet2 & $-27.39 * * *$ \\
& $(7.826)$ \\
DHHdet3 & $-27.57 * * *$ \\
& $(7.342)$ \\
DHHdet4 & $-35.19 * *$ \\
& $(16.74)$ \\
DHHdet5 & $-23.40^{* * *}$ \\
&
\end{tabular}




\begin{tabular}{|c|c|}
\hline & (7.855) \\
\hline DHHdet6 & $\begin{array}{c}-25.82 * * * \\
(6.811)\end{array}$ \\
\hline DHHdet7 & $\begin{array}{c}-16.64 * * * \\
(6.282)\end{array}$ \\
\hline DHHdet8 & $\begin{array}{c}-22.63^{* *} \\
(11.21)\end{array}$ \\
\hline DHHdet9 & $\begin{array}{l}-25.76 \\
(21.23)\end{array}$ \\
\hline DHHdet10 & $\begin{array}{c}-21.46 * * * \\
(8.276)\end{array}$ \\
\hline DHHdet11 & $\begin{array}{l}-18.15 \\
(13.82)\end{array}$ \\
\hline DHHdet12 & $\begin{array}{l}-3.762 \\
(14.56)\end{array}$ \\
\hline DHHdet13 & $\begin{array}{c}16.60 \\
(18.42)\end{array}$ \\
\hline DHHdet14 & $\begin{array}{c}-14.71^{* *} \\
(7.063)\end{array}$ \\
\hline DHHdet15 & $\begin{array}{c}-19.06 * * * \\
(6.775)\end{array}$ \\
\hline DHHdet16 & $\begin{array}{c}-5.186 \\
(8.606)\end{array}$ \\
\hline DHHdet17 & $\begin{array}{l}-6.363 \\
(6.802)\end{array}$ \\
\hline DHHdet18 & $\begin{array}{c}16.49 * * \\
(7.672)\end{array}$ \\
\hline DHHdet19 & $\begin{array}{c}-7.624 \\
(12.65)\end{array}$ \\
\hline DHHdet20 & $\begin{array}{c}4.805 \\
(7.707)\end{array}$ \\
\hline DHHdet21 & $\begin{array}{l}13.54^{*} \\
(8.176)\end{array}$ \\
\hline Dbland2 & $\begin{array}{c}1.312 \\
(2.813)\end{array}$ \\
\hline Dbland3 & $\begin{array}{c}-8.144 \\
(7.191)\end{array}$ \\
\hline Dbland4 & $\begin{array}{c}6.191 \\
(4.393)\end{array}$ \\
\hline Dbland5 & $\begin{array}{l}-26.05^{*} \\
(13.38)\end{array}$ \\
\hline Dbland6 & $\begin{array}{l}-4.030 \\
(10.02)\end{array}$ \\
\hline Dbland7 & $\begin{array}{c}3.545 \\
(3.544)\end{array}$ \\
\hline Dbland8 & $\begin{array}{c}1.567 \\
(8.529)\end{array}$ \\
\hline Dbland9 & $\begin{array}{c}1.072 \\
(3.091)\end{array}$ \\
\hline Dbland10 & $\begin{array}{c}3.810 \\
(2.819)\end{array}$ \\
\hline
\end{tabular}




\begin{tabular}{lc} 
Dbland11 & 2.239 \\
& $(3.760)$ \\
Dbland12 & -4.267 \\
& $(9.930)$ \\
Dbland13 & 3.467 \\
& $(4.485)$ \\
Dbland14 & 3.676 \\
& $(4.718)$ \\
Dbland15 & 4.630 \\
& $(4.691)$ \\
Dbland16 & -2.929 \\
& $(4.918)$ \\
eink_bhc & $0.00251^{* * *}$ \\
& $(0.000395)$ \\
Constant & $39.24 * * *$ \\
& $(7.735)$ \\
& 1,938 \\
Observations & 0.233 \\
R-squared & \\
\hline Standard errors in parentheses \\
*** $<<0.01, * *$ $<<0.05, * 0.1$
\end{tabular}

